\title{
HDAC6 Gene
}

National Cancer Institute

\section{Source}

National Cancer Institute. HDAC6 Gene. NCI Thesaurus. Code C26500.

This gene is involved in chromatin remodeling, repression of gene expression and cellular management of misfolded protein-induced stress. 